\title{
Brazilian version of the Burden Interview scale for the assessment of burden of care in carers of people with mental illnesses
}

\author{
Versão brasileira da escala Burden Interview para avaliação de \\ sobrecarga em cuidadores de indivíduos com doenças mentais
}

\author{
Marcia Scazufca \\ Departamento de Medicina Preventiva da Faculdade de Medicina da Universidade de São Paulo. São Paulo, SP, Brasil
}

\begin{abstract}
Introduction: Burden on informal carers of people with mental or physical illnesses has been studied for a long time. Several standardized instruments for the assessment of carer's burden have been developed. The Burden Interview is one of the most frequently used instruments. The aim of the present study is to examine the internal consistency and validity of the Brazilian version of the Burden Interview, designed to examine the burden in carers of individuals with mental illnesses.

Methods: Carers of patients with a diagnosis of depression, aged 60 or over, were assessed for burden (Burden Interview), emotional distress (SRQ-20) and their perception of patients' behavioral and mood disturbances (Behavioral and Mood Disturbance Scale - BMD). Socio-demographic information of patients and carers was collected with a standardized form. The reliability of the Burden Interview was assessed through its internal consistency. Construct validity was assessed through the exam of the associations of carers' burden with their perception of patients' behavioral and mood disturbances, and the carers' burden with carers' distress.

Results: Eighty-two carers of elderly patients with depression were included, being forty-eight $(58,5 \%)$ women. The internal consistency was good, with a Cronbach's alpha of 0.87 . The associations between total scores of the Burden Interview and total scores of the SRQ-20 $(r=0.37, p=0.001)$, and between total scores of the Burden Interview with total scores of $\mathrm{BMD}(\mathrm{r}=0.54, \mathrm{p}=0.001)$ were strong, and similar to other studies that examined those associations, indicating a good construct validity of the Brazilian version of the Burden Interview.

Discussion: The Brazilian version of the Burden Interview is a standardized and valid instrument that can be used in the study of the impact of mental and physical illnesses on informal carers.
\end{abstract}

Keywords Burden of care. Burden scale. Impact assessment. Validity. Reproducibility of results.

Resumo Objetivo: Sobrecarga em cuidadores informais de pessoas com transtornos mentais ou com doenças físicas tem sido estudada há muito tempo. Diversos instrumentos padronizados para avaliação da sobrecarga em cuidadores já foram desenvolvidos. A Burden Interview é um dos instrumentos utilizados mais freqüentemente. O objetivo deste estudo é avaliar a consistência interna e a validade da versão brasileira da escala Burden Interview para avaliação de sobrecarga em cuidadores de indivíduos com doenças mentais.

Métodos: Cuidadores de pacientes com diagnóstico de depressão com 60 anos ou mais foram avaliados para sobrecarga (Burden Interview), desconforto emocional (SRQ-20) e para as percepções sobre problemas no comportamento e humor dos pacientes (Behavioural and Mood Disturbance Scale - BMD). Informações sociodemográficas dos pacientes e cuidadores foram obtidas com um questionário padronizado. A confiabilidade da Burden Interview foi avaliada por meio da sua consistência interna. A validade de construção foi avaliada pelo exame da associação da sobrecarga dos cuidadores com suas percepções sobre a perturbação do humor e do comportamento dos pacientes, e da sobrecarga com a avaliação dos sintomas psiquiátricos comuns dos cuidadores.

Resultados: Foram incluídos 82 cuidadores de pacientes idosos com depressão foram incluídos, sendo que 48 cuidadores eram mulheres (58,5\%). A consistência interna foi boa, com um alpha de Cronbach igual a 0,87. As associações dos escores totais da Burden Interview aos escores totais do SRQ-20 ( $r=0,37, \mathrm{p}=0,001)$ e aos escores

Submitted on 26/7/2001. Reviewed on 5/10/2001 and 14/12/2001. Approved on 19/12/2001.

The project this paper is referred to was financed by Fapesp (Process number 96/06643-3). M. Scazufca received a grant from the CNPq-Brasília, Brazil, when she was carrying out this study. 
totais da $\mathrm{BMD}(\mathrm{r}=0,54, \mathrm{p}=0,001)$ foram fortes e similares às associações encontradas em outros estudos, indicando uma boa validade de construção da versão Brasileira da Burden Interview.

Discussão: A versão brasileira da Burden Interview é um instrumento padronizado e válido, que pode ser utilizado no estudo do impacto de doenças mentais e físicas nos cuidadores informais.

Descritores Sobrecarga no cuidador. Escala de impacto em cuidadores. Medição de impacto. Validade. Reprodutibilidade dos resultados.

\section{Introduction}

For more than 50 years, there have been policies to dehospitalize mentally ill people and to give priority to community care in Europe and the US. As a consequence, studies about informal carers of mentally ill people have proliferated, particularly regarding relatives of psychotic and elderly patients with dementia. ${ }^{1-3}$ These studies have tried to measure the burden of carers and the areas of the lives of the carers and of the families that were the most affected by the presence of the patient. They have also examined the characteristics of carers and of the patient, besides the situation of their lives that would most influence the carers' burden. More recently, several studies have assessed carers' burden as an outcome variable in the assessment of interventions. ${ }^{4}$ Along with the development of studies about carers, several instruments for burden assessment have been developed..$^{4-5}$ Among the possible burden dimensions that each instrument assesses there are the impact on: leisure and social life, the occupational, mental and physical health, financial situation, family interaction and routine, psychotropic intake, other people from out of house, children, the help with routine activities, the supervision and encouragement of patients, stress, stigma, concern, shame, guilt and global burden.

The Burden Interview ('BI') ${ }^{6-8}$ is one of the mostly used scales for burden assessment in carers of elderly patients with dementia. Despite being developed from its authors' clinical and research experience with elderly patients with dementia and their relatives, its items are comprehensive and deal with dimensions common to several mental and physical illnesses. Therefore, the 'BI' has been used to assess the burden of carers of elderly patients with dementia and of elderly people and adults with other mental and physical diseases, such as people who survived a stroke, people who have chronic illnesses and carers' burden of subaracnoid hemorrhagic patients. ${ }^{9-11}$ The 'BI' has been already translated into several languages and is used in many countries besides the US, where it was developed. ${ }^{12-14}$

The aims of this study are to present the translation into Portuguese of the Burden Interview and the study of the internal consistency and validity of this version.

\section{Methods}

\section{Sample}

Patients and their relatives were selected just after patients started treatment for depression in two geriatric mental health services in the city of São Paulo, Brazil (Instituto de Psiquiatria do Hospital das Clínicas da Faculdade de Medicina da Universidade de São Paulo - IPq-HCFMUSP - and Centro de Atenção Integrada à Saúde Mental da Santa Casa de São Paulo - CAISM). Inclusion criteria were: (i) aged 60 or more, (ii) to live or have frequent contact with a person considered as his/ her informal carer, (iii) to have a diagnosis of depression according to ICD-10, ${ }^{15}$ (iv) beginning of out-patient treatment of the first episode or to have a new depressive episode in the month before the interview, (v) to be an inhabitant of the Great São Paulo, (vi) to sign the informed consent. For each patient an informal carer was selected. Criteria for the choice of informal carers were: (i) patient's relatives or close people, involved in the care process, (ii) at least a weekly contact with the patient, (iii) not being paid to take care of the patient, (iv) when the patient had one or more eligible persons as his/her informal carers, the person who lived with the patient and had a closer contact with him/her was chosen, in the following order: spouse, children, siblings, other relatives, neighbors or close friends, (v) informed consent.

\section{Assessments}

A standardized questionnaire was used to obtain socio-demographic information about patients and their relatives and about patients' illness characteristics.

The following assessment instruments have been used:

\section{Burden Interview ('BI' $)^{6-8}$}

The Burden Interview is a 22-item instrument to assess carers' burden associated to the patient's functional and behavioral disability and to the situation at home (Table 1).

\section{Scale's items}

The 22 items reflect respondent's areas of concern such as : health, social and personal life, financial situation, emotional well being and interpersonal relationships. Items measure the objective and subjective burden reported by the carer but different scores are not obtained. The subjective way in which items are written favors the carer's emotional answer. The scale's last item is a general one, in which the respondent is asked to assess how much he/she considers to be burdened due to his/her caretaker role.

\section{Scale's application}

The scale was built to be self-applicable, but may be also applied by an interviewer. In these cases, the interviewer reads aloud each item and asks the respondent to point out the 
INSTRUÇÕES: A seguir encontra-se uma lista de afirmativas que reflete como as pessoas algumas vezes sentem-se quando cuidam de outra pessoa. Depois de cada afirmativa, indique com que frequência o $\mathrm{Sr} / \mathrm{Sra}$ se sente daquela maneira(nunca=0, raramente=1, algumas vezes=2, frequentemente=3, ou sempre=4). Não existem respostas certas ou erradas.

1. $\mathrm{O}$ Sr/Sra sente que $\mathrm{S}^{*}$ pede mais ajuda do que ele (ela) necessita?

O Sr/Sra sente que por causa do tempo que o $\mathrm{Sr} / \mathrm{Sra}$ gasta com S, o Sr/Sra não tem tempo suficiente para si mesmo (a)?

O Sr/Sra se sente estressado (a) entre cuidar de S e suas outras responsabilidades com a família e o trabalho?

O Sr/Sra se sente envergonhado (a) com o comportamento de S?

O Sr/Sra se sente irritado (a) quando S está por perto?

$\mathrm{O} \mathrm{Sr} / \mathrm{Sra}$ sente que $\mathrm{S}$ afeta negativamente seus relacionamentos com outros membros da família ou amigos?

$\mathrm{O} \mathrm{Sr} / \mathrm{Sra}$ sente receio pelo futuro de S?

O Sr/Sra sente que S depende do Sr/Sra?

O Sr/Sra se sente tenso (a) quando S esta por perto?

O Sr/Sra sente que a sua saúde foi afetada por causa do seu envolvimento com $\mathrm{S}$ ?

O Sr/Sra sente que o Sr/Sra não tem tanta privacidade como gostaria, por causa de S?

O Sr/Sra sente que a sua vida social tem sido prejudicada porque o Sr/Sra está cuidando de S?

$\mathrm{O} \mathrm{Sr} / \mathrm{Sra}$ não se sente à vontade de ter visitas em casa, por causa de $\mathrm{S}$ ?

O Sr/Sra sente que S espera que o Sr/Sra cuide dele/dela, como se o Sr/Sra fosse a única pessoa de quem ele/ela pode depender?

O Sr/Sra sente que não tem dinheiro suficiente para cuidar de S, somando-se as suas outras despesas?

O Sr/Sra sente que será incapaz de cuidar de S por muito mais tempo?

O Sr/Sra sente que perdeu o controle da sua vida desde a doença de S?

O Sr/Sra gostaria de simplesmente deixar que outra pessoa cuidasse de S?

O Sr/Sra se sente em dúvida sobre o que fazer por S?

O Sr/Sra sente que deveria estar fazendo mais por S?

$\mathrm{O} \mathrm{Sr} / \mathrm{Sra}$ sente que poderia cuidar melhor de S?

De uma maneira geral, quanto o $\mathrm{Sr} / \mathrm{Sra}$ se sente sobrecarregado (a) por cuidar de $\mathrm{S}^{\star *}$ ?

*No texto S refere-se a quem é cuidado pelo entrevistado. Durante a entrevista, o entrevistador usa o nome desta pessoa.

${ }^{*}$ Neste item as respostas são: nem um pouco $=0$, um pouco $=1$, moderadamente $=2$, muito $=3$, extremamente $=4$.

correct answer. The interviewer is advised to make an answer card, with big letters and numbers for each answer to help the respondent. The instructions to use the scale are at the beginning and must be read before the items are answered. The time period for the answers must be specified according to the aims of each study. The scale has been used in cross-sectional and longitudinal studies. In the current study carers were asked to assess the frequency in which items occurred during the month before the interview.

\section{Scores}

Each item of the scale is scored from 0 to 4 , being $0=$ never, $1=$ rarely, $2=$ sometimes, $3=$ quite frequently, $4=$ nearly always. This punctuation indicates to the respondent the frequency of each item. The last item of the scale is also scored from 0 to 4 , but the possible answers indicate how much the respondent is feeling burdened due to his/her role as a carer $(0=$ not at all, $1=$ a little, $2=$ fairly, $3=$ quite a bit, $4=$ very). All items must be rated. The scale's total score is obtained adding all items and may vary from 0 to 88 . The greater the total score, the greater the burden.

\section{Psychometric properties}

Studies of the original scale version, which inclued the assessment of its internal consistency with different subjects, obtained good results, with Cronbach's alpha index varying from 0.79 to $0.91 .^{7,16-17}$

Gallagher et al. ${ }^{16}$ assessed the test-retest of the scale's original version and obtained a good result (alpha $=0.71)$. The internal consistency and validity of BI have been also assessed in its Japanese version ${ }^{\mathbf{1 3}}$, presenting results similar to the original version (internal consistency : Cronbach's alpha $=0.93$; test-retest: $\mathrm{r}=0.76$ ).

\section{Translation into portuguese}

The Burden Interview scale was translated into Portuguese from its English original version by the study's author. After this translation it was back-translated into English by an independent researcher. Convergences and divergences in the translation and back-translation of the scale were discussed with other mental health researchers, who were used to the utilization of scales. One of the scale's author (SH Zarit) authorized its translation and use in studies in Brazil.

\section{Self-Report Questionnaire-20 (SRQ-20) ${ }^{18}$}

The SRQ-20 is a screening instrument for common mental disorders, widely used in several countries including Brazil. It was applied to assess carer's emotional distress. Each of its 20 items is rated as absent or present by the respondent (scores 0 and 1 , respectively). Higher scores represent higher levels of emotional distress. The score's range can vary from 0 to 20 . We used the cutoff score of $7 / 8$, based on a Brazilian study to differentiate between possible cases of mental disorders. ${ }^{18}$

\section{The Behavioral and Mood Disturbance Scale (BMD) ${ }^{19}$}

The BMD was used to assess carers' perception about the patient's mood and behavioral disturbance. The scale has 34 items. For each item the respondent points out the frequency in which it occurs and the answers vary from $0=$ never; to $4=$ nearly always (0-never; 1-rarely; 2-sometimes; 3-frequently; 4-always). The total score is obtained adding all 34 items; higher scores indicate a greater perception of mood and behavioral disturbance of patients. Scores range from 0 to 136 . In the current study we asked carers about the problems they perceived in the previous month. The BMD Portuguese version used in this study was translated from English into Portuguese by the author of 
this study and back-translated into English by an independent researcher. Inconsistencies in the translation were discussed by a group of mental health researchers. The analysis of the BMD internal consistency for the current study was considered good (Cronbach's alpha $=0.88$ ). The author of the current study does not know any other research protocol in Brazil that had used this scale or any reliability and validity study about its Portuguese version.

\section{Procedures}

Outpatients who fulfilled the study's inclusion criteria were selected by their psychiatrists and invited to participate in the study. After the informed consent, the psychiatrist collected socio-demographic data as well as information on the patient's depression characteristics. At the same day, a research assistant asked the patient who was the person he/she considered as his/her main carer. Whenever possible, both were interviewed at that same day, otherwise the interviews occurred in other occasion, at the hospital or at the patients' home. Two research assistants were responsible for the interviews with patients and carers. Each of them interviewed individually the patient or the carer.

\section{Analysis}

Analysis was performed with the software SPSS for Windows version 6.0. Descriptive analysis of the characteristics of patients and carers was followed by analysis to examine the internal consistency and validity of the Burden Interview scale to assess burden in carers.

\section{Internal consistency}

It was assessed analyzing the calculation of inter-item correlations, item-total correlation and the standardized alpha (Cronbach's alpha coefficient). The Cronbach's alpha coefficient offers information about how much the standard answers to the scale's items suggest they are empirically related. Since the 22 items of the BI scale assess the same concept (how much the carer feels burdened for his/her role to take care of a person with an illness), it is assumed that the scale's items are positively related. The estimated Cronbach's alpha coefficient allows to assess the internal consistency of a scale with several items, the scale being used once with the same population (Altman, 1991). We also tested if the internal consistency findings for the scale depended much on some of its items. For this analysis, one item at a time was withdrawn and we assessed the internal consistency of the scale with its remaining 21 items.

\section{Validity}

It was analyzed the construction validity that examines how much this measure is related to other theoretically related concepts. ${ }^{21}$ To examine the construction validity in this study we assessed the associations of the burden measure with the measure of the patient's behavioral and mood disturbance (BMD), and the association of the burden measure with the assessment of the carers' common psychiatric symptoms (SRQ-
20). Associations of the BI with the BMD and the SRQ have been widely discussed in the literature. ${ }^{13-14,19,22-27}$ The consistency of the results found in the current study with those described in the literature that involve different samples and places will be used to discuss the validity of the translation into Portuguese of the BI. A good validity will be that where the results found in the current study are similar to those described in the literature.

1. Association of the BI with the SRQ-20: Pearson correlation was used to assess the concordance between continuous variables (total score). The t test was used to assess the difference of means in the burden's total score between groups of carers with scores up to 7 in the SRQ (possible non-case) or 8 or more (possible case).

2. Difficult behaviors: Pearson correlation was used to assess the association between total burden scores and BMP.

\section{Results}

\section{Sociodemographic and clinical characteristics of patients and their carers}

Eighty-two patients were included in the study. Sixty-one patients $(74.4 \%)$ were women, the mean age of patients was 67.5 years (range: 60 to 85 years), and their schooling was in average 4.6 years. Seventeen patients $(20.7 \%)$ were illiterate. Twenty patients $(24.4 \%)$ had mild depression, 52 (63.4\%) moderate depression, and $10(12.2 \%)$ severe depression. Thirty-one patients (37.8\%) were ill for up to 6 months, and $11(13.4 \%)$ for more than 4 years. Fifty-one patients $(62.2 \%)$ did not refer to any depressive episode before the current one. Fifty-six patients $(68.3 \%)$ underwent out-patient treatment at CAISM, and $26(31.7 \%)$ at IPq-FMUSP.

Eighty-two carers were included, of whom 48 (58.5\%) were women. Carers' mean age was 55.4 years (range: 19 to 79 years). Carers had studied in average 7.3 years but $10(12.2 \%)$ were illiterate. Forty-five carers (54.9\%) were patients' spouses (18 wives and 27 husbands), and twenty-eight (34.1\%) were children (24 daughters and 4 sons). The kinship of the other 9 carers was: 2 siblings, 2 grandsons, 2 daughters-in-law, 1 niece and two friends. Seventy-four carers $(90.2 \%)$ lived with the patients. The average of contact hours per week between carers and patients was 59.7. The Burden Interview's total score mean was 31.1 ( $\mathrm{SD}=15.7$; range 7 to 73 ). The SRQ-20's total score mean for carers was 5.3 (range: 0 to 16), and 23 carers $(28.0 \%)$ had a score above the cutoff point of $7 / 8$ for a possible psychiatric case. The scale's total score mean which assessed the carers' perception about patients' behavioral and mood disturbance (BMD) was 44,1.

Internal consistency and validity of the Burden Interview scale

The Cronbach's alpha coefficient was 0,87 . The scale's internal consistency was almost not altered by the withdrawal of items (alpha with items' withdrawal: range 0,85 to 0.87 ). The inter-item correlation mean was 0,23 (range- 0,13 to 0,66 ). The item-total correlation range was 0,18 to 0,68 , and the weakest correlation was that of the total score with item 14 
and the strongest that of the total score to item 22 .

Carers who perceived more problems in the patients' behavioral and mood disturbance reported greater burden level (Pearson correlation coefficient: $r=0,54 ; \mathrm{p}=0,001$ ). Greater burden levels in carers were also associated to greater levels of their emotional distress (Pearson correlation coefficient: $r=0,37 ; p=0,001)$. The 28 carers classified as possible cases by SRQ-20 had greater burden means (mean $=37.4, \mathrm{SD}=14,3$ ) than carers that had not been classified as possible cases (mean $=28.6$; $\mathrm{SD}=15.7)$. The difference between these means was statistically significant $(\mathrm{t}=2,4 ; \mathrm{df}=80, \mathrm{p}=0,02 ; 95 \%$ C.I. 1,3 to 16,3$)$.

\section{Discussion}

\section{Methodological limitations}

There is no instrument considered as gold standard for burden assessment and, therefore, it is not possible to assess its operational validity. However, we assessed the construction validity.

The study did not examine the reliability between different interviewers. Respondents answered or pointed out their answer to each item, and, therefore, the assessment of the application concordance and/or interpretation between interviewers became pointless. The test-retest reliability also was not done as the study design did not preview a second interview with carers. The scale's reliability assessment was performed through the assessment of its internal consistency. We also focused on other aspects that would contribute to improve the reliability of the instrument, such as its structuration and its assessment standardization .

All subjects included in the study were under out-patient psychiatric treatment. The final sample of patients with depression and their carers was very heterogeneous regarding their socio-demographic and clinical characteristics (sex, age and schooling of patients and carers, depression severity and duration of illness, relationship between patients and carers and number hours of contact subjects.) This variability between included subjects is desirable in studies on reliability and validity of psychiatric instruments.

\section{Internal consistency and validity of the Burden Interview}

The scale's internal consistency assessment was good and similar to results found with the original instrument. ${ }^{7,13,16-17}$
The total item-score correlation was stronger with item 22 that precisely asks the respondent how much he/she feels burdened for his/her carer role. This finding indicates that the global assessment carers have of themselves is consistent.

The scale's construction validity was examined through the association of carers' burden and two other measures that in several studies appeared to be positively associated with burden. First, we examined the association of carers' burden with their perception concerning the patients' behavioral and mood disturbance. Next, we examined the association of the carers' burden and their emotional disturbance, assessed with the SRQ-20. Results showed strong positive associations between carers' burden to these two measures, similarly to results of studies in several countries that assessed the same associations (studies with the BMD scale, ${ }^{14,19,22,24-27}$ studies with the $\mathrm{SRQ}^{13,22-23}$ ). This fact suggests that the translation into Portuguese of the Burden Interview scale keeps the validity of the original document.

\section{Conclusions}

In Brazil there is little systematized information about relatives and other informal carers of patients living in the community who are mentally ill or have other diseases. Now that the Burden Interview scale is available in Portuguese, studies can use it to obtain empirical data about the impact of mental and physical diseases on patients' carers. Using this instrument it is possible to assess the implications of the disease on several aspects of carers' lives as well as the outcome of interventions meant to relieve carers' burden and to improve the family's quality of life.

\section{Aknowledgements}

The author would like to thank Doctors Paulo Rossi Menezes and Ana Teresa de A. R. Cerqueira for their help in the translation of the scale into Portuguese, to the psychologists Beatriz Spósito and Luciana Ferraz, for having interviewed the study's subjects and to Doctors Rita Ferreira and Mônica Scalco (IPq-HCFMUSP), and Regiane P. Garrido and Sérgio Tamai (CAISM-Santa Casa), for their help to ascertain subjects. Marcia Scazufca received a grant from CNPqBrasília, Brazil.

The project was funded by Fapesp (Process number 96/ 06643-3)

\section{Referências}

1. Kuipers E. Family burden in schizophrenia: implications for services. Soc Psychiatry Psychiatr Epidemiol 1993;28:207-10.

2. Zarit SH, Edwards AB. Family caregiving: research and clinical intervention. In: Woods RT, editor. Handbook of the Clinical Psychology of Aging. New York: Wiley; 1996. p. 333-68.

3. Burns A, Rabins P. Carer burden in dementia. Int J Geriatr Psychiat 2000;15:S9-S13.

4. Schene AH, Tessler RC, Gamache GM. Instruments measuring family or caregiver burden in severe mental illness. Soc Psychiatry Psychiatr Epidemiol 1994;29:228-40.

5. Platt S. Measuring the burden of psychiatric illness on the family: an evaluation of some ratings scales. Psychol Med 1985;15:383-93.

6. Zarit SH, Reever KE, Bach-Peterson J. Relatives of the impaired elderly: correlates of feelings of burden. Gerontologist 1980;20:64955 .

7. Zarit $\mathrm{SH}$, Anthony $\mathrm{CR}$, Boutselis M. Interventions with caregivers of dementia patients: comparison of two approaches. Psychol Aging 1987;5:502-9.

8. Whitlatch CJ, Zarit SH, von Eye A. Efficacy of interventions with caregivers: a reanalysis. Gerontologist 1991;31:9-14. 
9. Faison KJ, Faria SH, Frank D. Caregivers of chronically ill elderly: perceived burden. J Community Health Nurs 1999;16:243-53.

10. Carod-Artal FJ, Egido-Navarro JA, Gonzalez-Gutierrez JL, Varela de Seijas E. Perception of long term overload in caregivers of patients who have survived a stroke. Rev Neurol 1999;28:1130-8.

11. Buchanan KM, Elias LJ, Goplen GB. Differing perspectives on outcome after subarachnoid hemorrhage: the patient, the relative, the neurosurgeon. Neurosurgery 2000;46:831-8.

12. LoGiudice D, Waltrowicz W, McKenzie S, Ames D, Flicker L. Prevalence of dementia among patients referred to an aged care assessment team and associated stress in their cares. Aust J Public Health 1995; 19:275-9.

13. Arai Y, Kudo K, Hosokawa T, Washio M, Miura H, Hisamichi S. Reliability and validity of the Japanese version of the zarit caregiver burden interview. Psychiatry Clin Neurosci 1997;51:281-7.

14. Schneider J, Murray J, Banerjee S, Mann A. EUROCARE: a crossnational study of co-resident spouse carers for people with Alzheimer's disease: I - Factors associated with carer burden. Int J Geriatr Psychiat 1999;14:651-61.

15. WHO. The ICD-10 classification of mental and behavioural disorders: diagnostic criteria for research. Geneva: World Health Organisation; 1993.

16. Gallagher D, Rappaport M, Benedicy A, Lovelt S, Silver D. Reliability of selected interview and self- report measures with families caregivers. Paper presented at the Annual Scientific Meeting of the Gerontological Society of America. New Orleans; 1985.

17. Anthony-Bergstone CR, Zarit SH, Gataz M. Symptoms of psychological distress among caregivers of dementia patients. Psychol Aging $1988 ; 3: 245-8$.

18. Mari JJ, Williams P. A comparison of the validity of two psychiatric screening questionnaires in Brazil using ROC analysis. Psychol Med 1985;161:779-82.

19. Greene JG, Smith R, Gardiner M, Timbury GC. Measuring behavioural disturbance of elderly patients with dementia in the community and its effects on relatives: a factor analytic study. Age Aging 1982;11:121-6.

20. Altman DG. Practical statistics for medical research. London: Chapman \& Hall; 1991.
21. Goldstein JM, Simpson JC. Validity: definitions and applications to psychiatric research. In: Tsuang MT, Tohen M, Zahner GEP, editors. Textbook in Psychiatric Epidemiology. Chichester: Wiley; 1995. p. 229-42.

22. Pearson J, Verma S, Nellet C. Elderly psychiatric patient status and caregiver perceptions as predictors of caregiver burden. Gerontologist 1988;28:79-83.

23. Draper BM, Poulos CJ, Cole AM, Poulos RG, Erlich F. A comparison of caregivers for elderly stroke and dementia victims. J Am Geriatr Soc 1992;40:896-901.

24. Fadden G, Bebbington P, Kuipers E. Caring and its burdens: a study of the spouses of depressed patients. Brit J Psychiat 1987;151:660-7.

25. Jenkins JH, Schumacher JG. Family burden of schizophrenia and depressive illness. Brit J Psychiat 1999;174:31-8.

26. Harwood DG, Barker WW, Ownby RL, Bravo M, Aguero H, Duara R. Predictors of positive and negative appraisal among Cuban American caregivers of Alzheimer's disease patients. Int J Geriatr Psychiat 2000;15:481-7.

27. Patterson TL, Semple SJ, Shaw WS, Yu E, He Y, Zhang MY, et al. The cultural context of caregiving: a comparison of Alzheimer's caregivers in Shanghai, China and San Diego, California. Psychol Med 1998;28:1071-84.

28. Zarit SH, Zarit JM. The memory and behavior problems checklist 1987R and the burden interview (technical report). University Park (PA): Pennsylvania State University; 1987.

\section{Correspondência}

Marcia Scazufca

Departamento de Medicina Preventiva

Faculdade de Medicina da Universidade de São Paulo

Av. Dr. Arnaldo, 455

01246-903 São Paulo, SP

Fax: (0xx11) 3813-1463

E-mail: scazufca@usp.br 